\title{
Efektivitas Pelatihan Kebersyukuran untuk Meningkatkan Resiliensi pada Masyarakat di Daerah Rawan Bencana
}

\author{
${ }^{1}$ Alif Rodhiana, ${ }^{2}$ M. Farid, ${ }^{3}$ Noviekayati \\ Universitas 17 Agustus 1945 Surabaya, Semolowaru, Indonesia \\ Email: ${ }^{1}$ alifrodhiana@gmail.com, ${ }^{2}$ muhfaridrochim@gmail.com \\ ${ }^{3}$ noviekayati@untag-sby.ac.id
}

\begin{tabular}{l}
\hline Tersedia Online di \\
\hline http://www.jurnal.unublitar.ac.id/ \\
index.php/briliant
\end{tabular}

\begin{tabular}{l}
\hline Sejarah Artikel \\
\hline Diterima pada 14 Juli 2020 \\
Disetujui pada 3 September 2020 \\
Dipublikasikan pada 30 \\
November 2020 \\
Hal. 661-668 \\
\hline
\end{tabular}

\section{Kata Kunci:}

Masyarakat rawan bencana;

Pelatihan kebersyukuran;

Resiliensi.

\section{DOI:}

http://dx.doi.org/10.28926/briliant .v3i4.511

\begin{abstract}
Abstrak: Penelitian ini bertujuan untuk mengetahui apakah pelatihan kebersyukuran efektif dalam meningkatkan tingkat resiliensi pada masyarakat di daerah rawan bencana. Subjek penelitian berjumlah 48 orang adalah masyarakat di desa Kelutan Kecamatan Trenggalek Kabupaten Trenggalek Jawa Timur. Jenis penelitian yang digunakan adalah penelitian metoda eksperimen, dengan design One Group pretest posttest design. Skala resiliensi sebagai alat pengumpul data yang yang disusun oleh peneliti telah diuji validitas aitem dan estimasi reliabilitas. Hasil penelitian $U j i$ Paired Samples Statistics diperoleh nilai signifikansi terlihat sebesar 0.002 ( $\mathrm{p}<0.05)$. Artinya terdapat perbedaan rata-rata tingkat resiliensi pada masyarakat di daerah rawan bencana antara prestest dan posttest pada pelatihan kebersyukuran. Implikasi dari penelitian ini adalah ada pengaruh pelatihan kebersyukuran terhadap resiliensi masyarakat di daerah rawan bencana. Pelatihan kebersyukuran meningkatkan resiliensi resiliensi masyarakat di daerah rawan bencana banjir.
\end{abstract}

\section{PENDAHULUAN}

Dilihat dari kondisi geografisnya, gambaran topografi Indonesia merupakan daerah yang memiliki banyak kontur pegunungan dan lereng-lereng yang menjadi ancaman utama bencana banjir dan tanah longsor. Kabupaten Trenggalek merupakan wilayah Jawa Timur yang sering mengalami bencana alam. Daerah ini kerap terjadi bencana alam banjir. Curah hujan yang lebat dalam waktu yang lama bisa dipastikan Kabupaten Trenggalek tergenang banjir. Selama ini bencana banjir sangat berpotensi memakan kurban jiwa dan merusak infrastruktur. Kerugian yang dialami bukan hanya kerugian material tetapi juga psikologis warga bisa terganggu. Berdasarkan data yang ada di BPBD Trenggalak terdapat sepuluh kecamatan yang menjadi kurban banjir dan tanah longsor. Diantaranya adalah kecamatan Tugu, Suruh, Karangan, Trenggalek, Pogalan, dan Panggul. Sedangkan daerah terdampak longsor berada di kecamatan Durenan, Dongko, Pule, Suruh, Panggul dan Pogalan._(news.detik.com yang diunduh tanggal 24 Oktober 2019).

Data BPBD Kabupaten Trenggalek, Kecamatan Trenggalek merupakan salah satu daerah yang setiap tahunnya terdampak banjir dan tanah longsor. Data pada tahun 2016 hingga 2018, bencana alam tersebut sering terjadi dan ada yang 
menjadi korban di dalamnya. Warga sering mengalami stress yang berdampak pada gangguan psikologis yang diakibatkan oleh banjir.

Berdasarkan hasil wawancara dengan masyarakat terdampak, warga hanya mempunyai tempat tinggal di daerah itu yang sudah turun temurun ditempati. Sebagian warga yang bertahan di daerah tersebut mempunyai mata pencaharian sebagai petani, meski ada juga yang berjualan ataupun sebagai pegawai atau buruh. Ketika masyarakat di daerah rawan bencana memiliki kemampuan resiliensi yang baik, maka ketika suatu saat tertimpa bencana mereka dapat menata kehidupannya kembali pasca bencana tersebut terjadi. Individu yang memiliki kemampuan untuk keluar dari masalah dan kesulitan bahkan penderitaan disebut resiliensi. (Connor\&Davidson,2003). Kondisi lingkungan mempengaruhi individu menghadapi kesulitan yang dihadapi dalam kehidupannya. ConnorDavidson mengubah aspek-aspek resiliensi menjadi skala resiliensi yang diberi nama CD-RISC (Connor Davidson_Resilience Scale).

Rresiliensi pada individu dipengaruhi oleh empat faktor (Resnick,dkk,2011), yaitu : memiliki harga diri yang baik pada individu, social support terhadap penyelesaian masalah, emosi positif ketika menghadapi situasi yang genting, dan spiritualiatas yang memiliki pandangan individu percaya adanya Tuhan sebagai penolong setiap kesengsaraan. Subjek penelitian ini adalah masyarakat daerah rawan bencana banjir yang berada di Kabupaten Trenggalek, terdiri dari laki-laki yang berusia 41 sampai 65 tahun. Penelitian ini memiliki tujuan utama yaitu dengan menjadikan pelatihan kebersyukuran sebagai terapi, apakah ada pengaruhnya terhadap resiliensi mayarakat di daerah rawan bencana banjir.

\section{Pelatihan kebersyukuran}

Masyarakat desa Kelutan memiliki nilai bersyukur terhadap apa yang diperoleh dalam kehidupan, yang merupakan gambaran masyarakat yang beragama. Rasa syukur dapat dicapai oleh warga misalnya memiliki rasa kebahagian, pikiran damai, sehat jiwa dan ada kepuasan dalam interaksi antar sesama. Individu menjadi resilient dikarenakan adanya emosi positif seperti bersyukur, cinta dan simpatik, sehingga memiliki kepusan hidup, berkurangnya depresi, lebih tenang, dan merasa optimis (Fredricson dkk,2003). Mengatasi stres dan trauma dengan mengulang secara positif pengalaman yang negatif dapat terbantu dengan bersyukur (Kubau, Seligman, Peterson, Diener, Zack, Chapman \& Thompson, 2011).

Bersyukur terbagi manjadi dua jenis : 1 . Rasa berterima kasih yang kepada orang lain atau sesama yang disebut personal,. 2. Ungkapan terima kasih terhadap Tuhan yang disebut transpersonal (Seligman, Peterson,2004). Empat langkah sederhana untuk melatih kebersukuran, yaitu : 1. Pikiran akan hal yang tidak disyukuri diidentifikasi, 2. Pikiran akan hal yang untuk disyukuri diformulasikan, 3. Pikiran hal yang tidak disyukuri diganti dengan hal yang disyukuri, 4. Segera mengaplikasikan apa yang dirasakan dalam diri menjadi sebuah tindakan (Miler dalam Emmons dan Mc. Collough, 2004).

Melakukan serangkaian kegiatan memberikan pengetahuan dan ketrampilan kepada orang lain disebut pelatihan. Dalam penelitian ini dilakukan serangkain kegiatan untuk meningkatkan kemampuan seseorang untuk mensyukuri segala sesuatu baik dalam bentuk batin, perkataan, dan tingkah laku 
dinamakan pelatihan kebersyukuran dapat meningkatkan resiliensi. Emosi positif dan kebahagian tercipta dengan adanya rasa syukur (Emmon,2003). Penelitian ini menggunakan tehnik analisis data dengan menggunakan analisis uji t-Sample Berpasangan, sebagai pengolah data melalui program SPSS yang membandingkan rata-rata dua variabel dalam suatu group sampel tunggal.

Hipotesis : Ada pengaruh pelatihan kebersyukuran terhadap resiliensi masyarakat daerah rawan bencana banjir. Pelatihan kebersyukuran efektif meningkatkan resiliensi masyarakat di daerah rawan bencana banjir.

\section{METODE}

Metode penelitian dilakukan dengan menggunakan metode eksperimen, dengan pendekatan design One group pretest posttest design dengan skala resiliensi sebagai alat pengumpul data yang disusun oleh peneliti berdasarkan teori dan telah dilakukan try-out. Subjek penelitian adalah masyarakat di daerah rawan bencana Kab. Trenggalek Jawa Timur, tepatnya di desa Kelutan Kec Trenggalek. Karakteristik subjek pada penelitian ini adalah 1. Laki-laki usia 41-65 tahun, 2. Penduduk bertempat tinggal di desa Kelutan, Kec. Trenggalek, Kab.Trernggalek, Jawa Timur. 3. Tidak terdapat gejala psikotik. Peneliti mengambil sampel 48 orang. Peneliti melakukan penelitian selama sehari. Tehnik yang digunakan adalah tehnik non-probability sampling. Skala resiliensi dikembangkan berdasarkan konsep CD-RISC (Conner-Davidson Resiliensi Scale). Lima aspek resiliensi yaitu : 1. Aspek kompetensi personal seperti kegigihan, 2. Toleransi terhadap yang tidak menyenangkan, 3. Mudah menerima secara positif terhadap perubahan dan interaksi sosial yang baik, 4. Mampu mengendalikan situasi, dan 5. Spiritualitas. Pengembangan skala resiliensi terdapat dalam 77 aitem.

- Ada 45 aitem yang menunjukkan daya diskriminasi aitem lebih dari 0,300 yaitu aitem nomor 1, 4, 5, 6, 7, 8, 9, 10, 12, 13, 19, 20, 21, 24, 26, 31, 33, 34, $35,36,38,40,41,43,44,45,50,51,52,53,56,57,59,62,63,64,65,68,69$, $72,73,74,75,76,77$.

- Terdapat 32 aitem yang gugur karena tidak memiliki daya diskriminasi lebih dari 0.300 .

Kriteria dalam skala ini merupaka jenis skala resiliensi model Likert, dimana subjek diminta untuk memilih salah satu dari empat kategori jawaban yaitu : SS (sangat setuju), S (setuju), TS (tidak setuju), dan STS (sangat tidak setuju) dengan skor 1 sampai 4 . Berdasarkan uji coba skala resiliensi ada 45 aitem yang daya diskriminasi aitemnya lebih dari 0,33 dan estimasi reliabilitas alpha 0.700 .

Skala diberikan pada saat pretest dan posttest. Adapun proses dalam kegiatan pelatihan kebersyukuran diantaranya melalui tiga tahap yaitu tahap persiapan, tahap pelaksanaan, dan tahap akhir.

1. Tahap persiapan penelitian:

a. Melihat kondisi lingkungan sekaligus mencari subyek berdasarkan karakteristik penelitian.

b. Pengajuan proposal penelitian melalui proses seminar.

c. Perbaikan proposal penelitian dengan bantuan dosen pembimbing.

d. Proses survey ke daerah yang akan dijadikan tempat penelitian dan sekaligus mengajukan izin permohonan penelitian di daerah tersebut. 
e. Mengajukan surat izin kepada Kesbangpol Kabupaten Trenggalek.

f. Menetapkan waktu penelitian. Peneliti berdiskusi dengan Bapak Lurah desa Kelutan Kab. Trenggalek untuk menetapkan waktu penelitian. Berdasarkan hasil diskusi, maka ditetapkan untuk melakukan pelatihan dalam sehari.

2. Tahap pelaksanaan:

a. Pertemuan dilakukan di pendopo kelurahan. Pada 5 menit, pertama, fasilitator mengawali pertemuan dengan memperkenalkan diri dan menjelaskan tujuan pelatihan. Pada sesi ini bertujuan untuk membangun kepercayaan dan kenyamanan selama proses berlangsung. Kemudian fasilitator membangun komunikasi dengan subjek agar mereka dapat berkomitmen mengikuti pelatian dengan tertib. Pada sesi ini bertujuan untuk mengukur tingkat resiliensi subjek.

b. Fasilitator membagikan lembar pretest dan meminta subjek untuk mengisi lembar Pretest skala resiliensi telah dibagikan, selama 15 menit yang diawali mengisi lembar Inform Consent. Pada sesi ini bertujuan untuk mengukur tingkat resiliensi subjek.

c. Fasilitator mengajak subyek untuk duduk dengan posisi nyaman pada tempat masing-masing dan fokus mendengarkan isi materi yang disampaikan.

d. Fasilitator mempersilakan subyek memberikan tanggapan atau tahap selanjutnya subjek diberikan waktu untuk mengerjakan posttest skala resiliensi yang telah disediakan selama 15 menit. Dalam sesi ini bertujuan untuk mengukur tingkat resiliensi subjek menghadapi bencana.

3. Tahap Akhir

Pada 10 menit terakhir dilakukan evaluasi dan penutupan kegiatan pelatihan kebersyukuran. Kegiatan pelatihan kebersyukuran ditutup dengan doa yang dipimpin oleh petugas.

\section{Tehnik Analisis Data}

Penelitian ini bertujuan untuk mengetahuai hasil uji efektifitas pelatihan kebersyukuran dalam meningkatkan resiliensi masyarakat di daerah rawan bencana. Untuk dapat mengetahui terjadinya peningkatan resiliensi maka diperlukan uji t antar waktu (pretest dan posttest) yaitu Paired Sample t-Test , yang sebelumnya telah dilakukan uji asumsi normalitas sebaran.

Normalitas distribusi sebaran sekor variabel dapat diketahui melalui uji normalitas sebaran. Jika terjadi penyimpangan, seberapa penyimpangannya. Dalam penelitian ini, nilai sebaran data hasil pretest akan diuji dengan uji statistik Kolmogorov-Smirnov.

Tabel 1. Hasil Uji Normalitas Kebersyukuran

Kolmogorov-Smirnov

\begin{tabular}{lcccc}
\multicolumn{1}{c}{ Kelas } & & Statistic & df & Sig. \\
\cline { 2 - 4 } $\begin{array}{l}\text { Hasil Pelatihan } \\
\text { Kebersyukuran }\end{array}$ & Pretest & 0.125 & 48 & 0.060 \\
\hline
\end{tabular}

Dari hasil uji normalitas berdasarkan tabel di atas, dapat diketahui nilai signifikansi untuk pretest yaitu 0,060 (p>,05). Dikarenakan nilai signifikansi dari hasil pelatihan kebersyukuran tersebut lebih besar dari 0,05, maka data dapat 
dikatakan bahwa data kebersyukuran berdistribusi normal dan memenuhi asumsi uji normalitas.

HASIL

Tabel 2. Gambaran Tingkat Resiliensi prestest dan posttest pelatihan kebersyukuran di Desa Kelutan, Kab. Trenggalek, November 2019

\begin{tabular}{cccccc}
\hline Interval & Kategorisasi & \multicolumn{2}{c}{ Pretest } & \multicolumn{2}{c}{ Postest } \\
\cline { 3 - 6 } & & Frekwensi & $\begin{array}{l}\text { Presentasi } \\
(\%)\end{array}$ & Frekwensi & $\begin{array}{l}\text { Presentasi } \\
(\%)\end{array}$ \\
\hline $153-180$ & Sangat Tinggi & 19 & 39,6 & 17 & 35,42 \\
\hline $126-152$ & Tinggi & 25 & 52,1 & 26 & 54,16 \\
\hline $99-125$ & Sedang & 4 & 8,3 & 5 & 10,42 \\
\hline $72-98$ & Rendah & 0 & 0 & 0 & 0 \\
\hline $72>$ & Sangat & 0 & 0 & 0 & 0 \\
& Rendah & & & & \\
\hline
\end{tabular}

Dari hasil analisis pretest didapatkan bahwa tingkat resiliensi sebelum diberi pelatihan kebersyukuran terdapat 4 peserta $(8,3 \%)$ terkategori sedang, 25 peserta $(52,1 \%)$ terkategori tinggi, 19 peserta $(39,6 \%)$ terkategori sangat tinggi, dan peserta terkategori rendah atau sangat rendah tidak ada. Setelah diberi treadment berupa pelatihan kebersyukuran terjadi kenaikan tingkat resiliensi. Hasil posttest menunjukkan bahwa 5 peserta $(10,42 \%)$ berada pada kategori sedang, 26 peserta $(54,16 \%)$ berada pada kategori tinggi, 17 peserta $(35,42 \%)$ terkategori sangat tinggi, dan peserta yang terkategori rendah maupun sangat rendah tidak ada. Artinya bahwa pelatihan kebersyukuran dapat menaikkan tingkat resiliensi mulai kategori sedang ke kategori tinggi, dan dari kategori tinggi ke kategori sangat tinggi.

Analisa Pengujian Hipotesis

Tabel 3. Hasil Uji t Paired Sample Resiliensi

\begin{tabular}{lccc}
\hline Kebersyukuran & Mean & t & Sig \\
\cline { 1 - 2 } Pretest & 145,44 & $-3,217$ & 0,002 \\
\hline Postest & 149,33 & & \\
\hline
\end{tabular}

Hasil analisis data diperoleh $\mathrm{t}=-3,217$ dan signifikansi sebesar 0,002 $(\mathrm{p}<0,001)$, artinya terdapat perbedaan sangat signifikan antara sebelum pelatihan kebersykuran dengan sesudah pelatihan kebersyukuran. Pelatihan kebersyukuran sangat signifikan meningkatkan resiliensi. Resiliensi saat pretest (rata-rata $=$ 145,44) mengalami peningkatan saat posttest (rata-rata 149,33). Sehingga hipotesis yang menyatakan bahwa pelatihan kebersyukuran meningkatkan resiliensi masyarakat daerah rawan bencana terbukti.

Standar deviasi masing-masing subyek yang belum diberikan pelatihan kebersyukuran sebesar 15,056 dan yang sudah diberikan pelatihan kebersyukuran sebesar 16,607. Sedangkan standard error of mean masing-masing subyek yang belum diberikan pelatihan kebersyukuran adalah 2,173 dan yang telah diberikan pelatihan kebersyukuran sebesar 2,397. Dengan memperhatikan hasil mean antara pretest dan posttest dari pelatihan kebersyukuran didapatkan nilai resiliensi setelah 
diberikan pelatihan lebih tinggi daripada sebelum diberikan pelatihan kebersyukuran. Hal ini menunjukkan bahwa pelatihan kebersyukuran efektif dalam meningkatkan resiliensi pada masyarakat di daerah rawan bencana.

Materi yang disampaikan dalam pelatihan kebersyukuran memberikan gambaran pentingnya bersyukur dan dampak dari bersyukur, mampu membuat subjek berkurang kecemasannya dalam menghadapi musibah banjir. Ketika subjek dilatih untuk lebih sering mengucapkan kata-kata syukur sebagai wujud ucapan terima kasih kepada Tuhan dan sesama, maka tertanam pikiran positif tentang berbagai hal yang mereka alami dalam kehidupan. Termasuk ketika menghadapi musibah banjir yang dianggap sebagai ketakutan akan adanya bencana atau pikiran negatif lainnya, maka melalui pembiasaan mengucapkan kata-kata syukur menjadikan individu berangsur-angsur menggeser pikiran negatifnya dengan pikiran positif. Pembiasaan berpikir positif membuat individu meniadakan emosi negatif. Emosi positif bisa dibangun melalui bersyukur, optimisme meningkat, kecemasan terhadap masa depan berkurang, dan membangun kemampuan resiliensi menjadi lebih baik.

Tahapan Identifying Self, subjek diajak mengenali kebersyukuran dengan menampilkan video orang-orang yang selamat dari musibah, dan subjek diajak mengidentifikasi pelajaran apa yang bisa diambil dari video tadi. Subjek diajak mengenali perilku negatif seperti mudah mengeluh, mudah marah dan kecewa atas kejadian yang menimpanya dan menggantikan pemikiran positif, bahwa setiap peristiwa selayaknya disyukuri dan diterima sehingga tidak ada lagi rasa marah dan kecewa. Tahapan Tree Blessing (Seligman, 2009), tehnik kebersyukuran dalam hati. Subjek mengaplikasikan tehnik ini dalam kesehariannya, sehingga memiliki peningkatan dalam kebahagiaan yang bisa berdampak pada peningkatan resiliensi.

Tahapan berikutnya Positive self-talk, ditujukan untuk meningkatkan kemampuan bersyukur secara lisan, yang merupakan perwujudan kebersyukuran yang dapat diajarkan dan diasah (Snyder\&Lopez,2002). Subjek diminta untuk mengucapkan serangkaian kata positif pada diri secara rutin. Melalui tehnik ini subjek mampu mengurangi perasaan takut yang ada pada dirinya dan bisa meningkatkan resiliensi pada diri subjek saat menghadapi musibah bencana banjir.

Pada tahapan Gratitude letter, subjek mempraktekkan kebersyukuran melalui tulisan yang berisi perasaan terima kasih kepada siapa saja yang pernah berbuat baik kepadanya. Tehnik ini mampu memunculkan emosi positif pada subjek mengenai kejadian menyenangkan yang pernah dialami serta membuat subjek mampu menekan emosi negatif yang muncul, yang pada akhirnya akan meningkatkan resiliensi.

Testimoni pada akhir pelatihan, bisa menjadi bukti bahwa pelatihan kebersyukuran membuat peserta merasa lebih bersyukur, lebih tenang, dan tidak takut apabila musibah banjir datang. Ada yang mengatakan waktu pelatihan yang hanya sehari, seharusnya bisa lebih lama.

Rasa bersyukur yang dimiliki individu mampu membuat masyarakat meningkat resiliensinya dalam menghadapi bencana. Dari hasil analisis dapat dilihat bahwa hasil rata-rata (Mean) antara pretest dan posttest dari pelatihan kebersyukuran, dapat disimpulkan bahwa nilai resiliensi setelah diberikan pelatihan kebersyukuran lebih tingi dari pada sebelum diberikan pelatihan kebersyukuran. Hal ini menjadi bukti bahwa ada perbedaan rata-rata tingkat 
resiliensi pada masyarakat di daerah rawan bencana sebelum dan sesudah diberikan pelatihan kebersyukuran, dan hal ini menunjukkan bahwa pelatihan kebersyukuran efektif dalam meningkatkan resiliensi pada mayarakat di daerah rawan bencana.

\section{KESIMPULAN}

Bahwa pemberian pelatihan kebersyukuran dapat meningkatkan resiliensi kepada masyarakat di daerah rawan bencana. Karena rasa syukur dapat meningkatkan emosi positif dan menciptakan kebahagiaan. Rasa syukur juga meningkatkan rasa spiritualitas yang berakibat individu lebih menyadari kehadiran Tuhan dalam kehidupannya. Dengan rasa bersyukur akan meningkatkan ketahanan atau resiliensi masyarakat dalam menghadapi situasi bencana.

\section{SARAN}

Diharapkan masyarakat di daerah rawan bencana untuk lebih meningkatkan spiritualitasnya dan selalu bersyukur dalam menjalani kehidupan, karena rasa syukur adalah salah satu sisi spiritual yang dapat dilakukan secara intens sehingga dapat membuat individu merasakan kebermaknaan dalam hidupnya. Selain itu masyarakat di daerah rawan bencana dapat melakukan atau menerapkan suatu aktivitas yang dapat meningkatkan resiliensinya dengan cara selalu bersyukur akan setiap keadaan yang ada dan dapat menceritakan atau menggambarkan akan kebersyukurannya dalam menjalani hidupnya.

Bagi Pemerintah di Desa Kelutan hendaknya pemerintah daerah terutama daerah rawan bencana banjir seperti di Desa Kelutan untuk diadakan kegiatan pelatihan dan bimbingan kebersyukuran secara berkala kepada warganya agar tetap memiliki tingkat resiliensi yang tinggi dan dapat menjalankan kehidupan sehari-hari dengan baik. Bagi peneliti selanjutnya diperlukan jumlah sampel yang lebih banyak dari berbagai wilayah daerah rawan bencana yang lain, supaya efek positif dari pelatihan kebersyukuran bisa dirasakan lebih merata. Selain itu disarankan dapat menambah waktu pemberian pelatihan kebersyukuran, karena ada kemungkinan semakin lama pemberian pelatihan kebersyukuran akan semakin meningkatkan resiliensi pada masyarakat di daerah rawan bencana.

\section{DAFTAR RUJUKAN}

Connor, K. M., \& Davidson, J. R. T. (2003). Development of a New Resilience Scale: The Connor-Davidson Resilience Scale (CD-RISC). Depression and Anxiety, 18, 76-82

Emmons, R. A. \& McCullough, M.E. (2004). The Psychology of Gratitude.New York: Oxford University Press, Inc.

Emmons, R. A., \& McCullough, M. E. (2003). Counting Blessings Versus

Burdens: An Experimental Investigation of Gratitude and Subjective Well58

Being in Daily Life. Journal of Personality and Social Psychology, 84, 377389.Erlangga.

https://news.detik.com/berita-jawa-timur/d-4457576/pemkab-trenggalek

tetapkan-status- bencana-banjir-dan longsor (diunduh tanggal 24 Oktober 2019)

https://www.dibi.bnpb.go.id, 2018 (diunduh tanggal 24 Oktober 2019) 
McCullough, M, E., \& Emmons, R, A.. (2003). Counting blessings versus burdens: an experimental investigation of gratitude and subjective well- being in daily life. Journal of Personality and Social Psychology, 84 (2), 377-389.

McCullough, M, E., Emmons, R, A., \& Tsang, J, A. (2002). The grateful disposition: a conceptual and empirical topography. Journal of Personality and Social Psychology, 82 (1), 112-127. doi: 10.1037//0022-3514.82.1.112.

McCullough, M. E., Tsang, J. A., Emmons, R. A. (2004). Gratitude in Intermediate Affective Terrain: Links of Grateful Moods to Individual Differences and Daily Emotional Experience. Journal of Personality and Social Psychology, 86 (2), 295-309. The American Psychological Association, Inc.

Resnick, B., Gwyther, L, P., \& Roberto, K, A. (2011). Resilience in aging: concepts, research, and outcomes. New York: Springer.

--Gwyther, L, P., \& Roberto, K, A. (2011). Resilience in aging: concepts, research, and outcomes. New York: Springer 